\title{
Formulation of Innovation Policy: Case of Bandung Smart City
}

\author{
Chaereyranba Sholeh ${ }^{1}$, Sintaningrum ${ }^{2}$, Yogi Suprayogi Sugandi ${ }^{3}$ \\ ${ }^{1}$ Department of Public Administration, Faculty of Social and Political Sciences, Universitas Padjadjaran \\ (email: reyranba@gmail.com) \\ ${ }^{2}$ Department of Public Administration, Faculty of Social and Political Sciences, Universitas Padjadjaran \\ (email: sinta.ningrum@unpad.ac.id) \\ ${ }^{3}$ Department of Public Administration, Faculty of Social and Political Sciences, Universitas Padjadjaran \\ (email: y.suprayogi16@gmail.com)
}

\begin{abstract}
The aim of this study is to describe the policy innovation of the implementation of a smart city in Bandung. Heightening urban issues are becoming increasingly complex and limited resources are available to alleviate them, making the government to continue making policy innovations in order to improve the societal welfare. The smart city policy innovation implemented by the government of Bandung is expected to solve the priority problems of Bandung effectively and efficiently. In conducting a policy innovation, special attention should be paid to several important things such as regulation, community needs, and understanding the apparatus and those who contribute in the implementation of a smart city in Bandung. With the fulfillment of several policy innovation factors, the implementation of a smart city in Bandung can be successful and solve the problems that currently exist in the city. To analyze the smart city policy innovation in Bandung, the researchers used the policy innovation instrument phase from Susanna Borras and Charles Edquist. The method used in this research is a qualitative method with a descriptive analysis method, and data collection was carried out through literature and field study (observation, interview, and documentation). The result of this research is that the smart city policy innovation in Bandung has not been successfully implemented. This can be seen from the three instruments of policy innovation that have not been implemented in the implementation of a smart city in Bandung. The three instruments are a regulation instrument, an economic financial instrument, and a soft instrument.
\end{abstract}

\section{Keywords:}

public policy; policy innovation; smart city

\section{Introduction}

An uncontrolled increase in population and limited resources creates a variety of urban problems. In dealing with increasingly complex urban issues, the government has made several policy innovations. Policy innovation is regulated in Law Number 23/2014 on regional government, which stipulates that every city and regency government is given the flexibility to handle and select priority matters in accordance with their respective regional conditions so that it is expected to enhance local creativity and initiatives. The problems of a city, especially Bandung, have become so complex that conventional solutions can oftentimes no longer catch up with the speed of the problems' growth. In response to this, Bandung has made a policy innovation that is implementing a smart city to address urban problems. In 2014, Bandung was a city that 
sparked the implementation of a smart city and became a pilot city for other regions that began implementing the concept of a smart city (LAPI ITB, 2013) (Mursalim, 2017). In the context of public administration, a policy innovation has turned into a real practice that makes governments everywhere perform far better and become the most rational choice to prevent a country from various forms of failure (Utomo, 2016).

In applying policy innovation, Bandung decided to choose the "smart city" concept. A smart city is synonymous with an urban development model based on the utilization of human resources and technology as a capital for the improvement of development and prosperity of the society in the context of the agglomeration in a city (Angelidou, 2014). The city of Bandung is one of the first cities to implement smart-city infrastructure and won several awards, including the smart-city rating organized by the Association of Smart Indonesia Initiatives (APIC). A smart city is a city capable of using human resources, social capital, and modern telecommunications infrastructure to realize sustainable economic growth and a high quality of life, with prudent resource management through participatory community-based governance (Caragliu, Bo, \& Nijkamp, 2009). This can be seen from the implementation of modern telecommunications infrastructure in the form of smart government, smart living, a smart economy, smart branding, a smart society, and a smart environment.

At this time, the concept of a smart city becomes a necessity for local governments that want to solve urban problems. In solving the increasingly complex urban problems, the use of technology is an efficient and successful step in developed countries. Several cities in Indonesia have begun to apply the smart-city concept in the management and settlement of urban problems. Bandung is one of the pilot cities for other regions in the application of the smart-city concept and has granted smart-city systems to several cities in Indonesia ("Dirintis Sejak 2014", 2017). In general, the development of cities to become a smart city begins with the use of partial information and communication technology on priority issues. In solving the increasingly complex urban problems, the use of technology is an efficient and successful step in developed countries. Several cities in Indonesia have begun to apply the concept of a smart city in the management and settlement of urban problems. Bandung is one of the pilot cities for other regions in the application of the smart-city concept and has granted smart-city systems to several cities in Indonesia (Badan Perencanaan Pembangunan Daerah Kota Bandung, 2013).

The concept of Bandung as a smart city began in 2013 at the beginning of Ridwan Kamil's regime in collaboration with various elements in the preparation of Bandung Smart City(LAPI ITB, 2013). Since 2014, Bandung has 394 applications that support the smart city application (“Dirintis Sejak 2014", 2017). According to the Mayor of Bandung, the application of the smart-city concept has solved $70 \%$ of problems in Bandung (Ramadhani, 2016). It shows the seriousness of Bandung in the application of the concept of a smart city. The magnitude of the impact of the application of the smart-city concept and the number of cities that apply this concept became of interest to the writers to examine smart-city policy innovation, especially in Bandung.

Based on the description of the background above, smart-city policy innovation in Bandung becomes important to be studied with the perspective of policy innovation formulation in order to find out whether the policy innovation made by Bandung's city government is correct by paying attention to the phases in formulation of policy innovation. This study will deeply examine the phases of a formulation in making a policy innovation. Therefore, seeing the importance of a smartcity concept policy for urban areas, especially 
in Bandung and the absence of research that discusses smart-city policy innovation in Bandung, the researchers are interested in conducting the present study with title "Smart City Innovation in Bandung".

In the perspective of public administration, policy innovation is a new idea implemented by the government to solve all public problems (Borras \& Edquist, 2013; Edquist, 2011). Policy innovation plays an important role in the country's development and helps improve productivity and welfare (World Bank, 2010). Policy innovation is an improvement upon the existing things or the creation of a product, process, service, or organizational model to promote long-term economic growth and improve quality of life (Ezell \& Atkinson, 2010). Policy innovations began to be introduced in the mid-1990s and after that became popular and began to be implemented by both public and private organizations (Edler \& Fagerberg, 2017). According to Walker, policy innovation is a new policy for a country that adopts it, regardless of how obsolete the program is or the number of countries that have adopted such policies (Tyran, Jean-Robert, \& Sausgruber, 2003).

When conducting a complex policy innovation, according to Lundvall and Borras (1997), there are three features to consider before undertaking such policies; the competition policy, trade policy, and economic policy; Policies on ability to innovate and handle change such as human resource development; and policy innovation, and policies built to address problems in the transformation / change process (Johansson, Karlsson, \& Backman, 2007). When conducting policy innovation, an instrument is needed in formulating policy innovations so that the goals of a government can be achieved. The instrument of policy innovation becomes the decisive success of the innovation and innovation process of the policy itself. In a policy innovation, the instrument can be used as a supporter of the process of formulation and the implementation process of policy innovation (Borras \& Edquist, 2013).

In the formulating process, the instrument supports the creation of a product of policy innovation that will be made. Meanwhile, in the process of implementation, the instrument will play a role to direct the product of policy innovation to achieve the goal. This research will focus on the instruments in the implementation process. This is because smart-city innovation has entered the implementation stage. Thus, more policy-innovation instruments are needed (Borras \& Edquist, 2013).

In this study, there are several policyinnovation instruments proposed by several researchers. Research from Fan Li, Lynne Butel, and Peijie Wang (2017) revealed there are three instruments of policy innovation, namely Demand side is an instrument that emphasizes the involvement of others in the process of policy innovation. Supply Side is an instrument that puts more emphasis on improving the capacity of the organization as implementer in policy innovation. Environmental is characterized by considering the administrative aspects. In this case, it can be a procedure or a regulation that acts as a guide in implementing policy innovation. In this study, researchers focus on how local governments formulate innovation policy to address public issues.

While other research results Borras \& Edquist (2013) show three different policy innovation instruments, they are regulatory instrument, this instrument makes law as a rule in interaction during policy innovation process. This is related to the government's desire to make a guide during policy innovation. furthermore, other researchers argue that sanctions are important in policy regulation so that in the implementation of policy innovation, the implementer has guidelines, economic and financial instruments. This instrument influences the development and dissemination of innovation. In this process, demand is a current problem. This instrument involves the 
economic aspect into public policy innovation. Demand-focused instruments can help to correct this specific type of weakness. So, policy is made based on demand and the needs of the community and soft instruments. This instrument involves other parties in the implementation of policy innovations that are voluntary. Soft instruments provide recommendations or offer voluntary agreements and contracts. These instruments are very diverse, but are generally based on information exchanged between actors, and a hierarchical form of cooperation between the public and private actors.

Before the implementation of a smart city in Bandung, Bandung's city government made innovations about the use of technology, information, and communication. The innovation is evidenced by the creation of a master plan for the use of information and communication technology. The use of ICT by the government aims to create good governance and increase the effectiveness and efficiency of public services (Bandung Regional Development Planning Agency, 2013). However, according to Bandung's mayor, Ridwan Kamil, the innovations were not enough, so other innovations were made in the form of smart cities that could be more effective in solving urban issues. The factors of leadership and commitment of the Bandung city government became a factor of success in the implementation of a smart city in Bandung (Sunindyo, Akbar, \& Iqbal, 2013).

In other literature, there are several instruments of efficient policy innovation in technological innovation and development, including regulations (Mickwitz, Hyva"ttinen, \& Kivimaa, 2008). This instrument consists of permissions, rules, standards that are important in a policy. However, some opinions reveal that regulation may hamper innovation, but other opinions make it clear that regulations can increase the spread of innovation. In regulatory instruments, new existing requirements and tightening must be predictable and reliable in order to promote innovation. Economic Instrument: This instrument is superior in promoting innovation because it provides incentives for innovation and public R\&D funding. This is related to a partnership in conducting research on policy innovation. Research and development according to some experts rely on subsidies provided and most of the projects that receive funding are done in collaboration with several companies, academics, and research institutions.

\section{Methods}

In preparing this research, the authors used a qualitative research method with a descriptive analysis method. The qualitative approach was chosen because this research tries to describe the views of researchers as a whole and seeks to reveal in-depth truths about the policy innovation regarding the concept of a smart city conducted by Bandung's city government.

The authors use a qualitative research method with a descriptive approach because by using a qualitative method, the authors can understand more deeply about the phenomena that occur in the field. The final results of this research is that the researcher can give suggestions or recommendation about instrument of policy innovation, which is proper in smart-city implementation for Bandung. Qualitative research also provides more free space for researchers to explore information and data in the field. With this approach, the authors can express the views, attitudes, and experiences of informants as well as the values adopted by informants. All the information that the authors get in the field, both from research informants and documents, are delivered in a straightforward and sharp manner so that it can reveal the in-depth results of the research.

The research data used is descriptive research data, where in the early research the 
researcher collected data through the library study technique and field study (interview, observation, and document collection). In a qualitative study, researchers determine that the informants are the people who are directly related to the object of research. The informant determination technique used is the purposive technique, which is a technique of taking data sources with certain considerations. This technique uses people who are considered to know more about what we would expect in research in order to facilitate researchers explore the object/social situation under study. The technique used by researchers to test the validity of data in this study is triangulation. In this study, the authors applied two types of triangulation, i.e. the triangulation of data and sources. In this study, the authors used the data analysis technique by Miles and Huberman, which is an interactive model. The conclusion of a qualitative research is a new finding that had not previously existed. In this study, researchers identify policy innovations regarding the concept of a smart city in Bandung based on the theory of Borras and Edquist (2013).

Based on the process of System Mapping Study (SMS), there are some previous studies relevant to this research. Relevant research is used to look for similarities and differences between other people's findings with the research being studied or compared to one another. Researchers used the SMS process to search previous research that become reference material for their thesis which is current researcher write about " Policy Innovation of Smart City in Bandung". From the results of SMS, by searching policy innovation in the field of social science and management, there are several Scopus journals that examine the Elsevier, Routledge, and Oxford University Press.

Figure 1 shows that the Scopus database search results by searching the key string "Policy Innovation" and found 36 articles and 4 books. Furthermore, after going through the stages of search based on the process of Systematic Mapping Study, which includes inclusion criteria, only 28 articles were found. The next SMS result was done by grouping the writer/researcher according to the variables or focus of the theme that the researcher write. Based on the results of Systematic Mapping Study, which has tracked 36 journals and 28 journals that meet the inclusion factor, only 25 journals about Smart City Innovation Policy in Bandung obtained from scopus electric database. These findings indicate that this study is very interesting to study, considering the little amount of literature about previous research on smart cities in Indonesia.

Policy innovation has various forms, including smart city and e-government. Conceptually, the smart city is considered to

Figure 1.

Result of SMS Execution

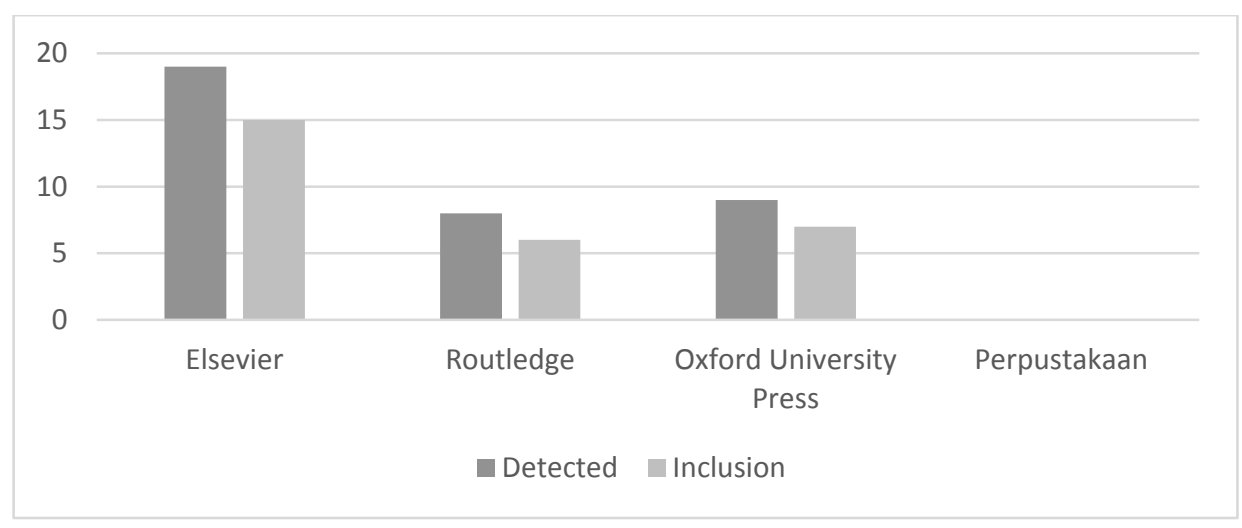

Source: Petersen, 2008 
be more effective in solving problems because it is not only talking about technology, but also discussing resources. When implementing e-government, it has three objectives, namely to restructure administrative functions and processes, to overcome barriers to coordination and cooperation within the public administration, and to monitor government performance. The smart city is discussed comprehensively by looking at aspects of a smart economy, smart mobility, smart governance, smart people, smart living, and smart environments. Therefore, the authors are interested in conducting research on smart city policy innovations in Bandung.

\section{Result and Discussion}

Along with increasing technological progress, it is utilized by the government in managing the city so that the concept of the "smart city" emerged. This concept originated from various paradigms of the city, namely the smart city, city information, city of knowledge, and digital city (Monfaredzadeh \& Berardi, 2015). Building a smart city brings its designers, managers, and citizens with lots of technical and social issues to solve. If the knowledge needed to solve the problem is complex, evolving, and widespread, the ability to collaborate is a must. Collaboration is a common decision-making process whereby all parties with an interest in the issue constructively explore their differences and develop common strategies for action. Compared to hierarchical forms of planning and decision making, collaboration has been shown to reduce risks, speed products to market, lower the cost of developing solutions and process improvements, and provide access to new knowledge, technologies, and markets. Collaboration can be a springboard for economic development in a city or region and can be used to increase citizen engagement. In the smart-city concept that requires collaboration, actors (government, private and public) are required to be more connected with each other and not just rely on bureaucratic hierarchy, real-time and more integrated integration of information and resources is urgently needed (Badan Perencanaan Pembangunan Daerah Kota Bandung, 2013). In order to access the necessary information the resources must be supported by adequate infrastructure and systems to achieve the concept of a smart city (Snow, Hakonsson, \& Obel, 2016).

The rapid development and industrial growth, as well as the cool air, make Bandung a destination for jobseekers, so the flow of urbanization becomes difficult to control. The concept of a smart city in Bandung is expected to answer at least three important things about a city, namely sensing the condition of the city, understanding the condition of the city further, and acting to the problems that arise (Diskominfo Kota Bandung, 2016). The smartcity concept is an innovation policy conducted by the government of Bandung in handling all urban problems that occur there. The smart-city concept is expected to make Bandung managed by using information and communication technology (ICT) to connect, monitor, and control various city resources more effectively and efficiently in order to maximize service to citizens and support sustainable development (LAPI ITB, 2013)

Yet, in the implementation of the concept of a smart city in Bandung, there are still some obstacles that are considered interesting for writers to review. Some obstacles perceived by Bandung's city government is the absence of regulation or legal basis governing the implementation of a smart city in Bandung. Although the concept of a smart city is mentioned in RPJMD Bandung in 2013 - 2018, there is no regulation that specifically discusses the implementation of the smart city. Bandung's city government divides several priority areas developed in a smart city, including Smart Government, Smart Education, Smart Transportation. Smart Parking, Smart Health, Smart Grid/Smart Energy, Smart Surveillance, 
Smart Environment, Smart Society/Smart Reporting/Bandung Passport, Smart Payment, and Smart Commerce. The absolute requirement of a smart city is ICT-based communication and connected quickly with the Internet network. Intense communication between officials and society or vice versa with officials without time lag makes it easy to make quick decisions (LAPI ITB, 2013).

Bandung Smart City does not solve the city's priority problems. While making a policy innovation, one must refer to the priority problems that occur so that policy innovation can made to solve the problem. In making policy innovation, it takes the role of academia private and public in helping the government implement policy innovation, which here is the implementation of smart city in Bandung.

In this study, the authors use the policy innovation instrument from Borras and Edquist (2013), where this theory reveals that there are three phases in a policy innovation. In the following section, the authors will describe three phases of policy innovation according to Borras and Edquist (2013). Among them are the set of rules governing the implementation of policy innovation, economic transfer, which is a policy made on demand and community needs, and soft instructure, which is the involvement of others in the implementation of policy innovation.

In the undertaking of policy innovation, the application of smart-city concepts needs an appropriate instrument to identify existing problems and be able to determine the objectives of policy innovation (Borras \& Edquist, 2013). In the preparation of a smart city in Bandung, smart-city implementers are divided into two functions, namely governance and management. Management functions performed by the service manager can be done by two parties, namely SKPD related in Bandung's city government as well as the private sector as a service provider. While the function of governance is done by the mayor as the holder of the mandate for the management of Bandung, DPRD as the people's representative and legislative power holder, the Strategic Committee will oversee the implementation of smart city in Bandung and Bandung Smart City Alliances as a communication forum and alliance among smart-city stakeholders in order to be able to contribute to each other in the progress of Bandung (LAPI ITB, 2013).

In making a policy innovation, policy implementers should pay attention to the needs of the community, because policy innovation should tend to solve the problems that occur. The city of Bandung has strategic issues contained in the RPJMD draft, which consists of 14 issues, namely environment, infrastructure, congestion, flood, waste, bureaucracy and governance reform, poverty reduction, poverty alleviation and social problems, slum area management and city revitalization, education, health, street vendors, culture, tourism and creative economy, community empowerment, and the development of information and communication technology. This strategic issue is based on urban issues and takes into account regional, national, and global strategic issues.

The results of a survey conducted by LAPI ITB is to be a reference in the implementation

Figure 2.

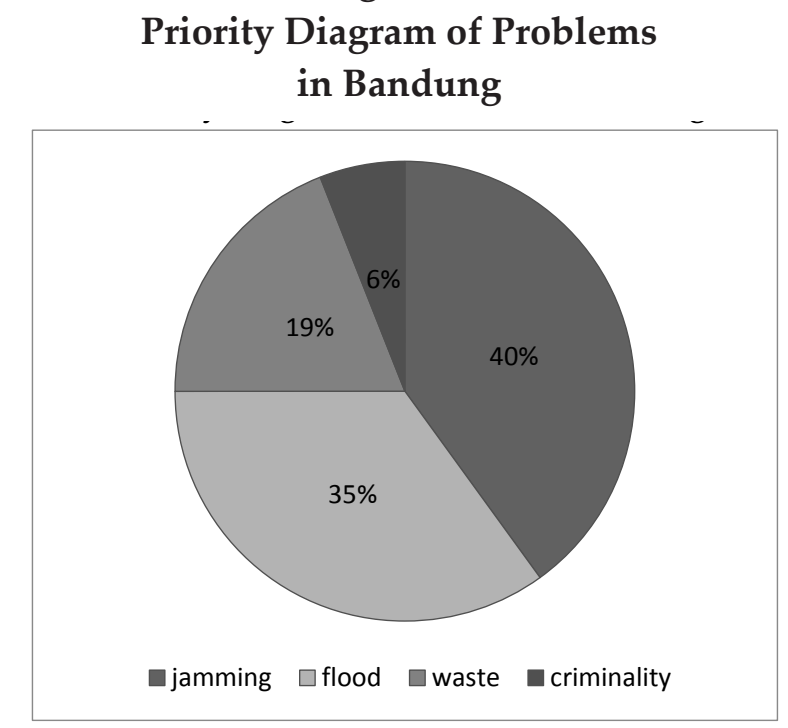

Source: (LAPI ITB, 2013) 
of Bandung Smart City by Bandung's city government as outlined in the Final Report Preparation of Master Plan Bandung Smart City. Based on the final report of Bandung City Intellectual Planning, the priority issue of Bandung is as follows:

The diagram shows that the main problem in Bandung is the congestion, which reaches $40 \%$. Thus, in making public policy innovation, Bandung's government needs to pay attention to the priority problems that occurred. According to the Head of Transportation and Parking Division at Bandung Transportation Department, a traffic jam can be caused by the increase of tourism in Bandung, Bandung's relatively narrow streets, and uncontrolled vehicle growth ("Mengapa Jalan di Bandung", 2017). The provision of public transportation has not been able to unravel congestion in Bandung, so this also needs special attention from the government of Bandung.

The implementation of a smart city in Bandung is described in the Strategic Plan of Bandung City 2013-2018 that is meant to realize Bandung Smart City. But ever since 2013, the application of the concept of Bandung Smart City does not yet have a regulation or legal basis that specifically discusses smart cities. This certainly has a major impact on the application of Bandung Smart City. In the context of public administration, the legal/regulatory basis is an important aspect of the activities undertaken by the government (Borras \& Edquist, 2013). The absence of guidelines and rules of smart city implementation also complicate the apparatus in implementing the concept of Bandung Smart City. According to Section Head of Bandung Communication and Information Service Office, in the absence of regulation or legal basis in the implementation of a smart-city concept, making the government apparatus that runs the concept becomes difficult, especially in integrating existing applications (personal communication).

Regulation or the rule of law has a very important influence in the process of policy innovation, because innovation is complex and very broad in government and community activities, so that necessary regulation or rule of law for innovation can run to achieve the expected goal. A smart city is one of the policy innovations undertaken by the regional head in solving all urban problems effectively and efficiently. Considering to implement Article 390 of Law No. 23/2014, government regulation is required to regulate regional innovation and to be ratified in 2017, namely Government Regulation No. $38 / 2017$. The government regulation aims to improve the performance of local government administration. The innovation of the region is expected to accelerate the realization of the welfare of the community through improving public services, empowerment and community participation, and the improvement of regional competitiveness. In Government Regulation No. 38/2017, Regional Innovation is defined as all forms of renewal in the implementation of local government. The form of innovation described by this Government Regulation is innovation of government governance, innovation of public service, and other regional innovation in accordance with government affairs which is the regional authority.

Smart-city policy innovation is a way for Bandung to overcome problems. Innovation becomes very important if the innovation can be a solution of existing problems in the city of Bandung. Therefore, it takes a very detailed guidance in the implementation of a smart city in Bandung. However, according to Head of Bappedalitbang 2011 (personal communication). in the implementation there are no guidelines and rules explained in the implementation of smart city, especially in Bandung. So since its implementation in 2014, until now the implementation of a smart city only refers to the Law and Government Regulations on regional innovation.

In the implementation of Bandung Smart City, there is no regulation that 
specifically explains the implementation of a smart city, especially in Bandung. Based on interviews with the head of Bandung Regional Development Planning Agency, there is no specific regulation set for Bandung. The implementation of Bandung Smart City only refers to Government Regulation Number 38 on Regional Innovation, but it has not specifically explained the implementation of a smart city. Based on Article 14 in Government Regulation No. 38/2017, it explained that in determining local innovation initiatives, the regional head decides the regional head on regional innovation accompanied by the establishment of regional apparatus according to its field to be assigned to carry out the regional innovation test. In the declaration of paragraph 1 of Article 14 it is very clear that the head of the region must make more detailed rules related to the innovation of smart cities.

However, based on interviews with informants, the Government Regulation Number 38/2017 only describes the governance and has not clearly explained the rules and guidelines for the implementation of a smart city. This will certainly be a problem in the future if the government has not set guidelines in the implementation of a smart city, considering that the concept of a smart city, especially in Bandung, has started to be applied in other areas. Based on the analysis of the researcher, there is incomprehension of Bandung State Civil Government Apparatus towards Government Regulation No. 38/2017. In Article 20 it is also explained in detail that the application of innovation is determined by Local Regulation or Perkada, while the Government of Bandung assumes that Government Regulation No. 38/2017 is considered sufficient in the implementation of a smart city in the city of Bandung.

The concept of a smart city as an innovation done by the city government should be able to solve priority problems that occurred in Bandung. Implementation of the concept of a smart city in Bandung continues to grow. Based on the final report of the Bandung City Intelligent Master Plan, one of the main objectives in making policy innovation by applying the concept of a smart city in Bandung is to eliminate congestion in Bandung. But at the smart city service distribution level there is no service from a smart city to cope with traffic congestion in Bandung (LAPIITB, 2013). Related to the solution of priority problems in Bandung such as congestion, there are 32 aspects that influence the traffic jam shown by the Transportation Department of Bandung City in the final report of the preparation of master plan Bandung Smart City. One of them is the provision of mass public transport. Currently, Bandung has developed a smart transportation service that aims to provide a safe, efficient, convenient, affordable, and environmentally friendly transportation system. But the provision of services is only one of 32 aspects of congestion prevention and has not been able to solve the congestion problem that occurred in Bandung.

Currently, the main priority of Bandung's city government is the development of a smart government. This can be seen from RPJMD Bandung that explained that the realization of Bandung Smart City aims to implement bureaucracy reform. Based on the author's initial observation, smart government is the main focus of the smart-city concept (personal communication). Smart government aims for local governments to perform their duties and functions in a prime way in the management of public services. According to Head of Bappedalitbang 2011 (personal communication) in the early stages, the government of Bandung focus on data collection to run a smart city in Bandung through smart government. In the smart government stage, one aspect related to a smart city is the issue of governance (governance), which is closely related to public services. The excellent service provided by the government apparatus becomes an obligation 
that cannot be negotiable in the present. Bandung City Government was aware of it. Especially with the current technological advances, and public dissatisfaction with public services can be quickly spread through social media and other media. Efforts to realize smart governance that will have the output of improving the quality of public services is done in various ways.

Data collection becomes the first step towards a smart city and facilitates the government in knowing the problems that occurred in Bandung. But this data-collection stage takes a long time, especially on the integration of smart government applications derived from 394 applications in which there are only 7 applications are integrated. Not only data collection, but policy, technology, and organizational aspects also become the success factor of a smart city (Taewoon \& Pardo, 2011). Figure 3 below outlines some applications that support the development of smart government in Bandung.

Efficient and effective governance becomes a demand in the era of globalization that is closely related to competition and limitations in all fields. This fact demands the professionalism of state apparatus resources in the conduct of government affairs. This current professionalism, however, is not yet fully realized. One of the main causes of this is because there is a mismatch between the competences of employees with occupied positions. Similarly, the distribution of employees still does not refer to the real needs of the organization, in a sense not yet based on the effectiveness of the work of the organization. Stacking employees in one unit without clear work and the lack of staff in other units is the reality of the problem. On the other hand, the formation of an organization tends to not be based on real needs in the sense that the organization is formed too large while the effectiveness of its work is small, so the achievement of organizational goals is ineffective and efficient.

However, referring to Figure 1.1, the main problem of Bandung is the bottleneck. As already mentioned, the application of a smart city in Bandung prioritizes smart government services. Whereas, in the concept of public administration, policy innovation should take into account the need to solve the problem (Borras \& Edquist, 2013). In policy innovation conducted by the city government of Bandung, the concept of a smart city has not been able to provide services to solve priority problems.

Figure 3.

Supporting applications for the Smart Government of Bandung

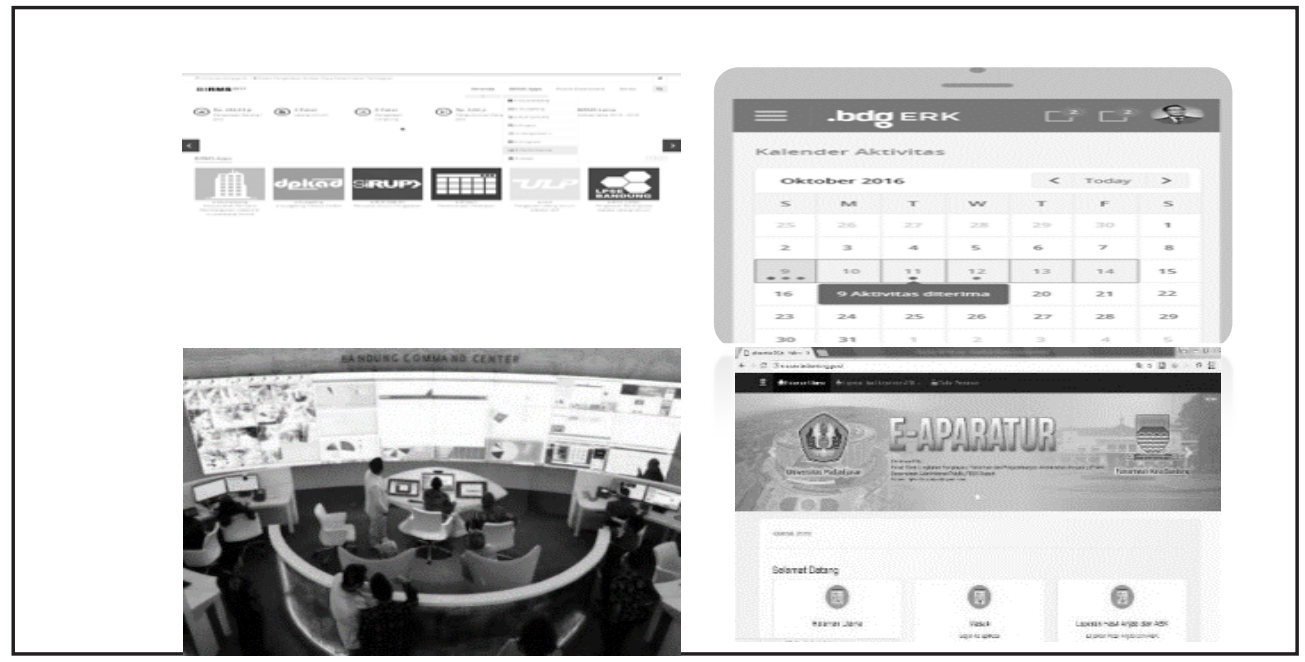

Source: Processed by Researchers, 2017 
With the mismatch between the main problems of Bandung and the innovation of smart-city concept policies, it became the author's interest to examine smart-city policy innovation in Bandung. Another factor that caused this study to be important is because there is no legal umbrella in the implementation of the smart city. In the observations with Kepla Bappedalitbang Kota Bandung, 2011 (personal communication), the authors found that until now the concept does not have a clear legal basis about the rules and guidelines in the implementation of a smart city.

The implementation of a smart city was only mentioned in the Regional Regulation No. 03/2014, which set forth in the RPJMD Bandung without clearly explained guideline implementations regarding the concept of a smart city in Bandung. In the context of public administration, the legal/regulatory basis is an important aspect of the activities undertaken by the government (Borras \& Edquist, 2013). The absence of guidelines and rules of smart city implementation also complicate the apparatus in implementing the concept of Bandung Smart City.

In policy innovation, good financial management is required, as either financial or financial management can serve to encourage or inhibit an innovation (OECD, 2017). In the implementation of smart city policy innovation in Bandung, financial management is a very important thing to note considering that the budget required by Bandung is very large in implementing smart-city infrastructure in Bandung. This is certainly not comparable with the APBD obtained by Bandung. In Government Regulation No. 38/2017, regional innovation activities have been determined by the regional heads as outlined in the Local Government Work Plan and budgeted in the Regional Budget (APBD) along with other funding in accordance with the provisions of legislation. With Bandung's limited budget, the city government utilized CSR funds from companies - companies that exist in the Bandung - by creating a forum called Social Allowance and Environment (TJSL) Bandung. Bandung has received 32 billion IDR from the private company TJSL, which is used to fund 180 activities including physical or non-physical development ("180 Kegiatan Kota Bandung", 2016). This forum consists of elements of government and development stakeholders of Bandung, including private elements, academics, and institutions. By 2016, this forum has collected and managed TJSL funds from 194 companies in a transparent and accountable manner.

\section{Conclusion}

The innovation policy of the smart city in Bandung is a new way to solve urban problems and regulations in Bandung. The existence of regulations is needed to ensure the performance of the apparatus and smartcity programs that are carried out as well as become a source of information and cover what restrictions can and cannot be made. In implementing the smart-city policy innovation in Bandung, which has been carried out since 2014, it does not have clear regulations. This will certainly be a problem in the future if the government has not compiled with guidelines in the implementation of a smart city considering that the concept of a smart city, especially in Bandung, has begun to be applied in other regions and are prone to irregularities and mal-administration.

Human resources are an important factor in the implementation of a smart city because it affects the development of sustainable innovation. In the case of Bandung, the human resources that is very influential is the mayor who initiated the smart city. But the ability of innovation is not in line with the ability in the government system that ignores regulation in a smart city. Besides that, not all ASNs have the capability to support a smart city, so they still use experts in the implementation of a smart city. 
The budget is an important sector for local governments in carrying out policy innovation, especially the implementation of a smart city in Bandung. The budgeting process is considered to be important because budgeting or financial management can function as a driver or as a barrier to policy innovation. However, since the implementation of a smart city in 2014, the new budget was classified in 2018 so that since the implementation of a smart city, there has been no priority budget planned for the implementation of a smart city. The capacity of the public sector to innovate also depends on the quality and effectiveness of institutional arrangements that support innovation. This arrangement can include institutionalizing innovation in government mandates.

In building a smart city, roles are needed from various parties, namely the government, academics, and the private sector to integrate and coordinate all components of the city when building a smart-city system. The Smart City Board, which comes from various backgrounds, was created by the mayor of Bandung in 2014 at the beginning of the smart-city implementation to support its success. However, the existence of the Smart City Board is currently not running effectively, so direct supervision by the mayor is needed along with mature tasks so that the smart city is an effective solution in solving urban problems.

In this study, researchers experienced limitations in gathering data about Bandung Smart City. The data limitation is due to the concept of the smart city that is still newly implemented and does not yet have regulations issued from the central government. Aside from that, the concept of a smart city is still a plan by Bandung's city government, so it does not yet have a clear concept of Bandung Smart City.

\section{References}

Angelidou, M. (2014). Smart city policies : A spatial aproach. Elsevier: Cities, 41, S3-S11.
Badan Perencanaan Pembangunan Daerah Kota Bandung. (2013). Masterplan teknologi informasi dan komunikasi Kota Bandung tahun 2013 - 2018. Bandung: Badan Perencanaan dan Pembangunan Kota Bandung.

Borras, S., \& Edquist, C. (2013). The choice of innovation policy instruments. Technological Forecasting \& Social Change, 80(8), 1-10. doi: 10.1016/j. techfore.2013.03.002

Bupati Bandung. (2014). Peraturan daerah kabupaten bandung nomor 3 tahun 2014 tentang perubahan keenam atas peraturan daerah Kabupaten Bandung nomor 23 tahun 2007 tentang pembentukan dana cadangan untuk pembebasan lahan untuk pembangunan jalan. Soreang.

Caragliu, Bo, C. D., \& Nijkamp, P. (2009). Smart cities in Europe. Business administration and econometrics, Series: Serie Research Memoranda.

Cohen, B. (2013). What exactly a smart city? Retrieved January 12, 2017, from http:// www.boydcohen.com/smartcities.html

Dirintis sejak 2014, Pemkot Bandung kini punya 394 aplikasi smart city. (2017, September 26). Pikiran Rakyat. Retrieved from Pikiran Rakyat: http://www.pikiran-rakyat.com/ bandung-raya/2017/09/26/dirintis-sejak2014-pemkot-bandung-kini-punya-394aplikasi-smart-city-410270

Diskominfo Kota Bandung. (2016). Fenomena Bandung smart city. Bandung: Diskominfo Kota Bandung.

Edler, J., \& Fagerberg, J. (2017). Innovation policy: What, why, and how. Oxford Review of Economic Policy, 33(1), 2-23.

Edquist, C. (2001). The Systems of innovation approach and innovation policy: An account of the state of the art. Paper presented at DRUID Conference. Denmark: Aalborg.

Edquist, C. (2011). Design of innovation policy through diagnostic analysis: 
Identification of systemic problems (or failures). Industrial and Corporate Change, 20(6), 1725-1753. doi: 10.1093/icc/dtr060

Ezell, S. J., \& Atkinson, R. D. (2010). The good, the bad, and the ugly (and the self-destructive) of innovation policy: A policymaker's guide to crafting effective innovation policy. Washington D.C: The Information Technology \& Innovation Foundation.

Johansson, B., Karlsson, C., \& Backman, M. (2007). Innovation policy instrument. Jonkoping, Sweden: CESIS .

Ramadhani, D. (2016, September 2). Ridwan Kamil: Dengan "Smart City", 70 persen masalah di Bandung Tuntas. kompas.com. Retrieved from http://regional.kompas. com/read/2016/09/02/14122821/ridwan. kamil.dengan.smart.city.70.persen. masalah.di.bandung.tuntas

LAPI ITB. (2013). Laporan akhir penyusunan rencana induk Bandung kota cerdas smart city. Bandung: Badan Perencanaan dan Pembangunan Pemerintah Kota Bandung.

Li, F., Butel, L., \& Wang, P. (2017). Innovation policy configuration - a comparative study of Russia and China. Policy Studies, 1-28. doi: 10.1080/01442872.2017.1308477

Mickwitz, P., Hyva“ttinen, H., \& Kivimaa, P. (2008). The role of policy instruments in the innovation and diffusion of environmentally friendlier technologies: Popular claims versus case study experiences. Journal of Cleaner Production, 162-170.

Monfaredzadeh, T., \& Berardi, U. (2015). Beneath the smart city: Dichotomy between sustainability and competitiveness. International Journal of Sustainable Building Technology and Urban Development, 140156. doi: 10.1080/2093761X.2015.1057875

Mursalim, S. W. (2017). Implementasi kebijakan smart city di Kota Bandung. Jurnal Ilmu Administrasi, 126-138.

OECD. (2017). Fostering innovation in the public sector. Paris: OECD Publishing.
Petersen, K. (2008). Systematic mapping studies in software engineering. In G. Visaggio, M.T. Baldassarre, S. Linkman, \& M. Turner (pp. 1-10). 12th International Conference on Evaluation and Assessment in software engineering. Italy: University of Bari.

Presiden Republik Indonesia. (2014). Undang undang Republik Indonesia nomor 23 tahun 2004 tentang pemerintah daerah. Jakarta: Presiden Republik Indonesia

Presiden Republik Indonesia. (2007). Peraturan pemerintah Republik Indonesia nomor 38 tahun 2007 tentang pembagian urusan pemerintahan antara pemerintah, pemerintah daerah provinsi, dan pemerintah daerah Kabupaten/Kota. Jakarta.

Snow, C. C., Hakonsson, D. D., \& Obel, B. (2016). A smart city is a collaborative community: Lessons from smart aarhus. California Management Review, 59(1), 92108.

Sunindyo, W. D., Akbar, S., \& Iqbal, M. (2013). Towards a smart world class city case: Building Bandung ICT master plan. International Conference on ICT for Smart Society (pp. 1-5). Jakarta: IEEE Xplore.

Taewoon, N., \& Pardo, T. (2011). Smart city as urban innovation: Focusing on management,policy and context. Proceedings of the 5 th International Conference on Theory and Practice of Electronic Governance. (pp. 185-194). U. S., State University of New York: Center for Technology in Government University at Albany.

Mengapa jalan di Bandung selalu macet, kata pejabat Pemkot Bandung jawabannya ini. (2017, July 18). Tribun Jabar. Retrieved from http://jabar.tribunnews.com/2017/07/18/ mengapa-jalan-di-bandung-selalumacet-kata-pejabat-pemkot-bandungpenyebabnya-ini

Tyran, Jean-Robert, \& Sausgruber, R. (2003). The diffusion of policy innovation: An 
experimental investigation. Departmen of Economics, Universitat St Gallen.

Utomo, T. W. (2016, January 23). Inovasi sebagai keniscayaan baru dalam ilmu dan praktek administrasi publik di Indonesia. Speech presented at Wisuda Sarjana ke-9 dan Magister ke-1 Sekolah Tinggi Ilmu Administrasi (STIA) in Indonesia, Bandung.
World Bank. (2010). Innovation policy: A guide for developing countries. Retrieved from https://openknowledge.worldbank.org/ handle/10986/2460.

180 kegiatan Kota Bandung pakai dana CSR Rp 32 miliar. (2016, December 16). Pikiran Rakyat. Retrieved from http://www.pikiranrakyat.com/bandung-raya/2016/12/16/180kegiatan-kota-bandung-pakai-dana-csr-rp32-miliar-388006 